\title{
Turkish EFL Teachers' Assessment Preferences and Practices in the Context of Constructivist Instruction
}

\author{
Turgay Han (Corresponding author) \\ Dept. of English Language and Literature \\ Faculty of Science and Letters, Kafkas University \\ Paşaçayırı Kampüsü, 36100 Kars, Turkey \\ Tel: 90-554-622-0962Ｅ-mail: turgayhan@kafkas.edu.tr \\ Halil İbrahim Kaya \\ Dept. of Educational Sciences, Faculty of Education, Kafkas University \\ Paşaçayırı Kampüsü, 36100 Kars, Turkey \\ Tel: 90-537-062-0536_E-mail: hik_kaya@hotmail.com
}

Received: Dec. 25, 2013 Accepted: January 12, 2013 Published: February 1, 2014

doi:10.5296/jse.v4i1.4873 URL: http://dx.doi.org/10.5296/jse.v4i1.4873

\begin{abstract}
The Ministry of Education in Turkey has been launching education programs based on constructivist learning since 2005 and this approach has led to innovation and renewal in education and teaching environments. This shift in education applications may have caused some changes in the education process, in educational tools and materials, in the design of learning environments and in testing and assessment. With a constructivist approach, multiple assessments for multiple learning applications are required to evaluate the extent to which the goals of an education program are being realized. However, assessment practices and purposes are mostly affected by teachers' beliefs and attitudes about assessment. In this sense, the aim of this school survey is to investigate the assessment practices and habits of Turkish teachers of the English language. Further, this study investigates the teachers' preferences, views, thoughts and feelings about assessment. This study was conducted with the participation of 95 Turkish EFL teachers working at primary and secondary schools in different districts of a city in Turkey. The data was collected through a questionnaire. The descriptive results showed that the teachers give less importance to listening and writing skills and also that speaking is perceived as the most challenging skill to assess. Furthermore,
\end{abstract}




\section{Macrothink}

the inferential statistical results showed that male and female teachers have similar assessment preferences in their teaching process. Class size impacts upon the teachers' assessment preferences significantly. Further, the teachers do not change their assessment preferences even if they receive assessment training during or before service and they frequently rely upon their personal assessment preferences. Finally, teaching hours and the number of quizzes did not affect their assessment preferences. The implications for education policy and practices are highlighted.

Keywords: English-as-a-foreign-language (EFL), Assessment preference, Constructivist approach, Education program, EFL teacher 


\section{Introduction}

Turkey is one of the leading non-European countries to frequently consider adapting Western innovations to its own education context. In particular, the Ministry of Education in Turkey has been launching radical changes in the curriculum of school education for more than two decades. In the curriculum of elementary school education in Turkey, the shift away from traditional (behaviorism-based) education towards constructivism-based education began to be implemented in the 2005-2006 academic year. Further, parallel to the new curriculum that was developed based on the constructivist approach; teacher-training programs in Turkey were also aligned with the sophisticated philosophical changes in teaching and learning (Arslani, 2007).

\subsection{Constructivism}

Based on the cognitive developmental theory of Piaget and the socio-cultural theory of Vygotsky, the constructivist approach has recently surfaced as the prevailing model in education and has contributed to the development of pedagogy (Kaufman, 2004). Frameworks focusing on socio-cultural factors (Moll, 1990b cited in Rueda \& Garcia, 1996) and cognitive psychology or information-processing theoretical frameworks have recently impacted extensively upon education professionals and on researchers' views on learning and assessment (McLaughlin, 1994; Padilla \& Sung, 1992 cited in Rueda \& Garcia, 1996). These frameworks emphasize, "how each individual constructs knowledge in the teaching/learning process" and "the individual as a part of a larger social context or activity setting", in other words they emphasize "constructivism, higher-order thinking, and self-regulation" (Rueda \& Garcia, 1996, p.314).

\subsection{Teaching, assessment, and testing}

With the emergence of constructivism, new roles have gained importance for teachers, who now need to be not just providers of information but also the assistants of learners as well as educational leaders (Christie, 2005). In the contemporary world, teachers have begun to develop a great interest in constructivist approaches to education, with the intention of developing better classrooms and schools, in the belief that constructivist approaches facilitate learning by linking the newly learned information with pre-existing knowledge (Arslani, 2007). Therefore, the constructivist approach does not conceive of "teachers as transmitting knowledge to learners", rather it assumes that students uses several strategies to grasp new information through "analyzing data to detect patterns, forming and testing hypotheses, and integrating new knowledge with previous understandings" (Rueda \& Garcia, 1996, p.314). In constructivism-based curriculums, "the learning outcomes, the learning and teaching methods and assessment methods should follow on one from another and be seamlessly, demonstrably interrelated" (Rust, O'Donovan \& Price, 2005, p.232). These fresh perspectives about learning have initiated "a rethinking of the educative process and a rethinking of the nature of assessment" (Office of Learning and Teaching, 2005, p.3).

The assessment of student attainment has recently been at the center of attention for their teachers, parents, educational professionals and in education systems, and this consideration 
has accentuated the integration between assessment and teaching and learning (Office of Learning and Teaching, 2005). In this sense, as described by Heaton (1975),"both testing and teaching are so closely interrelated that it is virtually impossible to work in either field without being constantly concerned with the other" (p.5). The literature on learning and teaching largely suggests that "assessment is at the heart of the student experience" (Brown \& Knight, 1994, p1. cited in Rust, O'Donovan \& Price, 2005, p.231) and that it is "an ongoing process" (Brown, 2004, p.4). For example, when a student gives answers to questions and produces new sentence structures, the teacher assesses the student's performance, even though this may be unintentional (Brown, 2004). Further, some types of performance, like writing, are continually assessed either by the student himself, or by his teachers or peers (Brown, 2004). When teachers perform assessment, they deal with measurement and with the progress the students have made and they also give feedback to the students after diagnosing their learning problems (Harris \& McCann, 1994, p.1).

It is essential for teachers to adapt new assessment practices in their constructivism-based curriculums. In the constructivist approach, learner performance is assessed in authentic contexts, such as the use of portfolios, writing tasks, etc. (Rueda \& Garcia, 1996). The basic aim in constructivist measurement is not to assess how much knowledge is remembered by the student but rather to assess how information is structured and how much the level of students' knowledge has changed throughout the learning process (Atasoy, 2004 cited in Arslan, 2009). In other words, constructivist assessment is more related to the process than to the outcome. As such, student writing and speaking performance can provide evidence of how they construct meaning (Akar, 2003).Therefore, in this new assessment culture, students become more actively engaged in their learning and assessment process through self- and peer assessment (Office of Learning and Teaching, 2005).

\subsection{Assessment in Language Teaching}

As is the case with instruction, "assessment practices are in a state of flux" (Rueda \& Garcia, 1996, p.315), thus the shift in learning and teaching methods can also be seen in the assessment of performance (Rueda \& Garcia, 1996). Although language teachers employ various assessment practices in their teaching, they may feel that they lack the skill to assess students' performance appropriately. Essay-type exams and term papers are preferred over standardized tests in constructivist education and authenticity enhances the reliability of the assessment (Akar, 2003). Therefore alternative assessment methods like portfolios, self-assessment, peer-assessment, etc. gain importance in a constructivism-based teaching and learning environment. These alternative forms of assessment are considered to be "a movement for the reform of school based assessment, away from standardized multiple choice tests and towards assessments which are more sensitive to the goals of curriculum" (McNamara, 2000, p.131). This alternative assessment approach integrates assessment with the goals of curriculum in order to yield a constructive relationship with learning and teaching (McNamara, 2000). Instead of using standardized tests that often have several negative sides, this approach "typically includes portfolio assessment, exhibitions, records of participation in classroom activities, etc.” (McNamara, 2000, p.131). 
In the field of EFL/ESL performance assessment, four major language skills are frequently tested in the following ways (Heaton, 1975, p.8):

-listening (auditory) comprehension, in which short utterances, dialogues, talks and lectures are given to the testees;

-speaking ability, usually in the form of interviews, picture description, role plays, and problem-solving tasks (e.g. pair work or group work);

-reading comprehension, in which questions are set to test the students' ability to understand the gist of a text and to extract key information on specific points in the text; and

-writing ability, usually in the form of letters, reports, memos, messages, instructions, and accounts of past events, etc.

Another basic question in language teachers' minds is "When should we assess our students?" (Bachman \& Palmer, 2010; p.26). In respect of assessment in general, formative and summative assessment approaches regarding the decisions made about students' achievement or progress comes into the scene (Brown, 2004). Formative assessment comprises "evaluating students in the process of 'forming' their competencies and skills with the goal of helping them to continue that growth process" (Brown, 2004; p.6). Therefore, it is more about informing students about their progress and scaffolding to make them more proficient learners (Harriss \& McCann, 1994, p.90). On the other hand, summative assessment is about measuring or summarizing "what a student has grasped, and typically occurs at the end of a course or unit of instruction" (Brown, 2004, p.6). The assessment practices used to promote learning in formative assessment are more parallel to the requirements in this new assessment culture (Office of Learning and Teaching, 2005). In respect of assessment in schools, teachers have three different preferences or approaches in relation to formative and summative assessments in schools: Assessment of Learning, Assessment for Learning and Assessment as Learning (Earl, 2003). Assessment of Learning is summative assessment which intends "to certify learning and report to parents and students about students' progress in school, usually by signaling students' relative position compared to other students" (Earl, 2003, p.2). On the other hand, Assessment for Learning is formative assessment which feeds back to teachers to create efficient learning by modifying teaching and learning activities during the ongoing instructional process (Gonzales \&Aliponga, 2012). Assessment as Learning is "a process of developing and supporting metacognition for students", focusing on students who act as the "critical connector between assessment and learning", and also students as critical analysts of their own learning (Manitoba Education, 2006, p.13). "Students monitor their own learning and use the feedback from this monitoring to make adjustments, adaptations, and even major changes in what they understand" (Manitoba Education, 2006, p.13). Assessment for Instruction is more concerned with teachers' use of assessment results to examine and improve the ongoing instructional process (Sheppard, 2000 cited in Gonzales \& Aliponga, 2012). Further, teachers "provide each student with accurate descriptive feedback to further his or her learning" if they prefer assessment for instruction (Earl \& Katz, 2006, p.85). Finally, Assessing to Inform is more about the communicative function of assessment in terms of "reporting and utilizing results 
for various stakeholders” (Jones \& Tanner, 2008 cited in Gonzales \& Aliponga, 2012, p.5).

From teachers' perspectives, "a growing literature suggests that teachers' beliefs affect both their perceptions and judgments and that these in turn affect their classroom behavior" (Rueda \& Garcia, 1996, p.312). In their comparative study, Rueda and Garcia (1996) investigated teachers' perspectives on literacy assessment and instruction with language-minority students, adapting a constructivist perspective on teachers' beliefs, which considers teachers to be "knowing, meaning-making beings whose knowledge and meaning influence their actions" (Rueda \& Garcia, 1996, p.312). Recently, Gonzales and Aliponga (2012) investigated the classroom assessment preferences of 61 Japanese language teachers in the Philippines and 55 English language teachers in Japan, using the Classroom Assessment Preferences Survey Questionnaire for Language Teachers (CAPSQ-LT). The results indicated that language teachers from both countries most frequently preferred assessment as learning and least frequently preferred assessment practices that refer to the communicative function of assessment. Further, Japanese language teachers preferred assessment for learning but the English language teachers in Japan engaged in the assessment of learning and the communicative and administrative function of assessment. The two groups had similar assessment preferences for assessment of learning and assessment as learning.

Although teachers have been trained to assess language performance appropriately, their personal judgments influence the way they behave in their classroom assessment activities (Gonzales \&Aliponga, 2012). As reported by Gonzales and Aliponga (2012), previous studies have frequently investigated either teachers' beliefs or conceptions of assessment and learning or students' perceptions of assessment. However, the existing literature reveals that there has been no study pertaining to Turkish EFL teachers' assessment preferences and practices, as used in secondary schools. In this regard, this study is significant because it is believed that the findings of the study will shed light on future studies and provide feedback to teachers, assessment professionals and decision makers on curriculum development. In this sense, this study builds a bridge between the assessment expectations of constructivism-based language curriculums and the assessment practices and preferences of EFL teachers in respect of foreign language assessment.

The following research questions guided this study:

1. What are Turkish EFL teachers' assessment perceptions? And what assessment practices do Turkish EFL teachers frequently employ?

2. What are Turkish EFL teachers' assessment preferences?

3. Are there any significant differences in the EFL teachers' assessment preferences according to their gender, educational degree, class size, teaching experience, and their former training on assessment?

\section{Method}

Using an adapted version of the Classroom Assessment Preferences Survey Questionnaire for 
Language Teachers (CAPSQ-LT) (Gonzales \& Aliponga, 2012), the aim of this study was to investigate English teachers' evaluation practices and their perceptions of EFL performance assessment in the context of Turkish secondary schools. Ninety-five Turkish EFL teachers voluntarily answered the questionnaire. A series of descriptive and inferential statistical techniques were used to examine the data, using the SPSS computer program. The guiding research question of this study is "What are the Turkish EFL teachers' assessment preferences and practices?

\subsection{Participants in the study}

Ninety-five teachers ( 73 females and 22 males) from among 253 teachers of English working at primary and secondary schools in different districts of a city in Turkey responded to the questionnaire voluntarily. Their ages ranged from 25 to 40 and they had different EFL teaching experience.

\subsection{Instrument}

The instrument was an adapted version of the Classroom Assessment Preferences Survey Questionnaire for Language Teachers (CAPSQ-LT) (Gonzales \& Aliponga, 2012). The first section of the questionnaire includes questions about participants' assessment perceptions, the assessment tools they use, their background and demography. The second section includes 35 items about the following five levels of teachers' assessment preferences (Gonzales \& Aliponga, 2012):

a) Assessment as Learning: Including ten items, this level examines the impact of assessment on learning.

b) Assessment of Learning: Including seven items, this level examines "conducting classroom assessment to learn alternative approaches to assess learning outcomes, and evaluate the level of competence of students at the end of an instructional program" (p.7).

c) Assessment for Learning: Including six items, this level examines "doing classroom assessment to provide feedback to students in order to improve their learning process, and make suggestions to students about how they develop better learning strategies" (p.7).

d) Assessment for Instruction: Including six items, this level examines "conducting classroom assessment to enhance the quality of classroom instruction, and explore effective classroom teaching methods and strategies" (p.7).

e) Assessing to Inform: Including five items, this level examines "doing classroom assessment to provide information to parents about the performance of their children in school, and examine how one student performs relative to others in a class" (p.7).

Gonzales and Aliponga (2012) found the following reliability properties of the questionnaire: a) "Cronbach's alpha coefficients that range between .822 (for assessing to inform) and .939 (for assessment as learning)", and b) "the complete questionnaire has total reliability index of .964 and the five factors can explain $64.45 \%$ of the variance measured by the questionnaire" (p.7). 


\subsection{Obtaining the Data}

The teachers of English working in primary and secondary schools in different districts of a city in Turkey provided the questionnaire data necessary for the analysis. The data were collected in multiple stages. In the first stage, before obtaining the data, permission was received from the office of the Ministry of Education in the city. In the second stage, teachers of English in the schools were invited to participate by the office. In the third stage of data collection, by visiting all teachers at their schools, they were first informed briefly about the context of the study and then invited to participate in the study voluntarily. The data collection took place in the spring semester of the 2012-2013 academic year.

Using Microsoft EXCEL, first the data obtained for the study were recorded and encoded and then double-checked for the purpose of data integrity. Finally, using the SPSS computer program, a series of descriptive statistics and inferential statistics (e.g. mean, standard deviations, t-test, and ANOVA) were produced.

\section{Results}

First, descriptive statistics were produced to examine the teachers' assessment perceptions and practices. Next, independent sample t-tests were conducted to determine the teachers' assessment preferences by gender. The purpose of these analyses was to examine whether there was a significant difference between the mean scores based on gender. The results are presented in Table 1. Next, Table 2 presents the one-way ANOVA test that was conducted to examine whether there was a significant mean score difference in terms of teachers' assessment preferences by class size. Further, independent Samples t-Tests were conducted to examine whether the teachers' assessment preferences differed as a function of their in-service training background and pre-service training background. The results are presented in Table 3 and Table 4. Finally, one-way ANOVA Tests were conducted to investigate if the teachers' assessment perceptions differed based on the number of courses taught in a week and quizzes given. The results are presented in Table 5 and Table 6.

\subsection{Descriptive statistics}

Descriptive statistics were conducted to investigate the teachers' perceptions about the assessment of language skills and the assessment practices the teachers frequently employ to judge their students EFL performance during an academic year. The results are presented in Table 1. 


\section{Macrothink}

Journal of Studies in Education

ISSN 2162-6952

2014, Vol. 4, No. 1

Table 1. The Teachers' perceptions about language assessment and tools

\begin{tabular}{|c|c|c|}
\hline Items & $\mathbf{F}$ & $\%$ \\
\hline \multicolumn{3}{|c|}{ What language skill(s) is/are the most important for your teaching? } \\
\hline Reading Skills & 45 & 47.4 \\
\hline Listening Skills & 20 & 21.1 \\
\hline Writing Skills & 29 & 30.5 \\
\hline Speaking Skills & 40 & 42.1 \\
\hline I give equal importance to all & 43 & 45.3 \\
\hline \multicolumn{3}{|l|}{ What language skill do you most frequently assess? } \\
\hline Reading Skills & 70 & 73.7 \\
\hline Listening Skills & 15 & 15.8 \\
\hline Writing Skills & 42 & 44.2 \\
\hline Speaking Skills & 32 & 33.7 \\
\hline \multicolumn{3}{|l|}{ Which skill is the most challenging for assessment? } \\
\hline Reading Skills & 17 & 17.9 \\
\hline Listening Skills & 34 & 35.8 \\
\hline Writing Skills & 30 & 31.6 \\
\hline Speaking Skills & 46 & 48.4 \\
\hline \multicolumn{3}{|l|}{ I assess Listening (Auditory) Comprehension through } \\
\hline Short utterances. & 31 & 32.6 \\
\hline Dialogues & 73 & 76.8 \\
\hline Talks and lectures & 28 & 29.5 \\
\hline Others & 2 & 2.1 \\
\hline \multicolumn{3}{|l|}{ I assess Speaking Ability through } \\
\hline Interviews & 27 & 28.4 \\
\hline A Picture description & 35 & 36.8 \\
\hline Role plays & 50 & 52.6 \\
\hline A problem-solving task (e.g. pair-work or group work) & 33 & 34.7 \\
\hline \multicolumn{3}{|l|}{ I assess Reading Comprehension through } \\
\hline Multiple choice questions & 50 & 52.6 \\
\hline True / false questions & 75 & 78.9 \\
\hline Ordering ideas task & 26 & 27.4 \\
\hline Others & 3 & 3.2 \\
\hline \multicolumn{3}{|l|}{ I assess Writing Ability through } \\
\hline Letter writing & 35 & 36.8 \\
\hline Report writing & 13 & 13.7 \\
\hline Memo writing & 13 & 13.7 \\
\hline Message writing & 26 & 27.4 \\
\hline Instructions writing & 36 & 37.9 \\
\hline Accounts of past events, etc. & 45 & 47.4 \\
\hline
\end{tabular}

The descriptive results in Table 1 indicate that the teachers give less importance to listening 
and writing skills, respectively $(21.1 \%$ and $30.5 \%$ ), while most of the teachers give more importance to reading and speaking skills $(47.4 \%$ and $42.1 \%)$. Further, nearly half of the teachers give equal importance to the four basic foreign language skills in their teaching $(45.3 \%)$. Next, the teachers most frequently assess reading skills during the academic year (73.7\%) while they assess listening skills the least frequently $(15.8 \%)$. Nearly half of the teachers assess writing skills the most frequently (44.2\%).

Regarding the teachers' perceptions about the challenges of assessing skills, they reported that speaking is the most challenging skill to assess $(48.4 \%)$, while reading is the least challenging one $(17.9 \%)$. For listening and writing skills they have similar perceptions (35.8\% and $31.6 \%$ respectively). Further, the teachers frequently assess listening skills through dialogues $(76.8 \%)$, while they less frequently use short utterances and talks and lectures (32.6\% and $29.5 \%$ respectively). Half of the teachers assess speaking skills through role plays $(52.6 \%)$, on the other hand picture description, a problem-solving task (e.g. pair-work or group work) and interviews are used at similar levels $(36.8 \%, 34.7 \%$ and $28.4 \%)$. Most of the teachers assess reading comprehension through true/false questions $(78.9 \%)$ while they use the ordering ideas task strategy less frequently $(27.4 \%)$ Nearly half of the teachers assess students' reading comprehension levels through multiple-choice questions $(52.6 \%)$. Finally, for writing skills, they usually use the following techniques: accounts of past events, etc., writing instructions, letter writing, and message writing (47.4 \%, $37.9 \%$, $36.8 \%$ and $27.4 \%$ ), respectively, they rarely use report and memo writing techniques $(13.7 \%)$.

\subsection{Inferential Statistics}

Table 2, Table 3, Table 4 and Table 5 show inferential statistical results regarding teachers' assessment preferences based on several variables (e.g. gender, classroom size, courses taught weekly, quizzes given, and the teachers' in- and pre-service educational background).

Table 2. Comparison of assessment preferences by gender

\begin{tabular}{|c|c|c|c|c|c|c|c|}
\hline Assessment preference & $\begin{array}{l}\text { Male } \\
\text { teachers }\end{array}$ & $\begin{array}{l}\text { Female } \\
\text { teachers }\end{array}$ & $\begin{array}{l}\text { Male } \\
\text { teachers }\end{array}$ & $\begin{array}{l}\text { Female } \\
\text { teachers }\end{array}$ & & & \\
\hline & $\mathrm{m}$ & sd & $\mathrm{m}$ & sd & $\mathrm{t}$ & $\mathrm{df}$ & $\mathrm{p}$ \\
\hline Assessment as learning & 37.91 & 4.74 & 38.37 & 5.21 & -.371 & \multirow{5}{*}{93} & .712 \\
\hline Assessment of learning & 27.32 & 3.63 & 26.96 & 4.28 & .357 & & .722 \\
\hline Assessment for learning & 24.00 & 4.31 & 24.85 & 3.97 & -.863 & & .390 \\
\hline Assessment for instruction & 22.95 & 3.34 & 22.55 & 3.89 & .443 & & .659 \\
\hline Assessment to inform & 22.45 & 3.58 & 22.37 & 3.78 & .093 & & .926 \\
\hline
\end{tabular}

Table 2 shows that there is no significant difference between male and female teachers' assessment preferences about their students EFL performance ( $p>.05)$. In other words, male and female teachers have similar assessment preferences in their teaching process. Yet, they mostly prefer assessment practices that focus on assessment as learning rather than assessment to inform. This result suggests that they mostly depend on constructivism in their teaching process. 
Table 3. Comparison of teachers' assessment preferences by class size

\begin{tabular}{lllllllll}
\hline \multirow{2}{*}{ Assessment Preferences } & \multicolumn{3}{l}{$\begin{array}{l}\text { Less than } 15 \\
\text { students }\end{array}$} & \multicolumn{2}{c}{$16-25$ students } & \multicolumn{2}{l}{$\begin{array}{l}\text { More than } 25 \\
\text { Students }\end{array}$} & \multirow{2}{*}{ F } \\
\cline { 2 - 7 } & $\mathrm{m}$ & $\mathrm{sd}$ & $\mathrm{m}$ & $\mathrm{sd}$ & $\mathrm{m}$ & $\mathrm{Sd}$ & \\
\cline { 2 - 7 } Assessment as learning & 3.70 & .86 & 3.75 & .87 & $\mathbf{3 . 9 4}$ & .86 & 1.791 \\
Assessment of learning & 3.96 & .79 & 3.74 & .92 & $\mathbf{3 . 9 7}$ & .90 & 1.820 \\
Assessment for learning & 4.22 & .70 & 3.95 & .91 & $\mathbf{4 . 2 6}$ & .85 & 2.550 \\
Assessment for Instruction & 3.70 & .81 & 3.61 & .81 & $\mathbf{3 . 9 7}$ & .84 & $3.701^{*}$ \\
Assessment to inform & $\mathbf{4 . 0 6}$ & .76 & 3.56 & .90 & 3.86 & .93 & $4.143^{*}$ \\
\hline
\end{tabular}

An ANOVA analysis was conducted to examine whether teachers' assessment preferences of EFL performance differ based on the number of students in a classroom. The results presented in Table 4 show that teachers with more than 25 students in their classes scored higher than those who have less than 15 students and those with 16-25 students, except for the factor on assessing to inform. However, two significant differences for the factors of assessment for instruction and assessment to inform were obtained, indicating that the teachers' two assessment preferences (e.g. assessment for instruction and assessment to inform) differ based on the number of the students in their classes.

Table 4. Comparison of assessment practices between teachers with and without pre-service assessment training

\begin{tabular}{|c|c|c|c|c|c|c|c|c|c|}
\hline \multirow[t]{2}{*}{ Assessment preference } & \multicolumn{3}{|c|}{$\begin{array}{l}\text { With pre-service } \\
\text { assessment training }\end{array}$} & \multicolumn{6}{|c|}{$\begin{array}{l}\text { Without pre-service } \\
\text { assessment training }\end{array}$} \\
\hline & $\mathrm{n}$ & $\mathrm{m}$ & sd & $\mathrm{n}$ & $\mathrm{m}$ & sd & $\mathrm{t}$ & $\mathrm{df}$ & $\mathrm{P}$ \\
\hline Assessment as learning & \multirow{5}{*}{83} & 38.37 & 5.15 & \multirow{5}{*}{12} & 37.50 & 4.74 & .554 & \multirow{5}{*}{93} & .581 \\
\hline Assessment of learning & & 27.12 & 4.30 & & 26.50 & 2.71 & .485 & & .629 \\
\hline Assessment for learning & & 24.81 & 4.15 & & 23.58 & 3.18 & .980 & & .329 \\
\hline Assessment for instruction & & 22.83 & 3.65 & & 21.33 & 4.38 & 1.296 & & .198 \\
\hline Assessment to inform & & 22.39 & 3.84 & & 22.42 & 2.84 & -.027 & & .979 \\
\hline
\end{tabular}

Table 4 compares teachers who received assessment training and those who did not receive any formal assessment training in their pre-service education and further whether the training impacted upon their assessment preferences. The results show that there is no significant difference between the teachers who do or do not have a pre-service assessment training ( $p>$.05) background, indicating that teachers' assessment preferences for EFL performance do not differ based on their pre-service training background. However, both the teachers with and those without pre-service assessment training scored higher in assessment as learning. 
Table 5. Comparison of assessment preferences between teachers with and without in-service assessment training

\begin{tabular}{|c|c|c|c|c|c|c|c|c|c|}
\hline \multirow[t]{2}{*}{ Assessment preference } & \multicolumn{3}{|c|}{$\begin{array}{l}\text { With in-service } \\
\text { assessment training }\end{array}$} & \multicolumn{6}{|c|}{$\begin{array}{l}\text { Without in-service } \\
\text { assessment training }\end{array}$} \\
\hline & $\mathrm{n}$ & $\mathrm{m}$ & sd & $\mathrm{n}$ & $\mathrm{m}$ & sd & $\mathrm{t}$ & df & $\mathrm{P}$ \\
\hline Assessment as learning & \multirow{5}{*}{59} & 38.34 & 5.23 & \multirow{5}{*}{36} & 38.14 & 4.91 & .185 & \multirow{5}{*}{93} & .854 \\
\hline Assessment of learning & & 27.34 & 4.33 & & 26.56 & 3.77 & .898 & & .372 \\
\hline Assessment for learning & & 24.75 & 4.31 & & 24.50 & 3.61 & .286 & & .775 \\
\hline Assessment for instruction & & 22.64 & 3.88 & & 22.64 & 3.60 & .006 & & .995 \\
\hline Assessment to inform & & 22.56 & 3.96 & & 22.11 & 3.32 & .568 & & .572 \\
\hline
\end{tabular}

Table 5 compares teachers who received writing assessment training and those who did not received any formal assessment training in their in-service education and further whether the training impacted upon their assessment preferences. Similar to the results set out in Table 4, the results show that there is no significant difference between the teachers who do or do not have an in-service assessment training ( $p>.05)$ background, indicating that teachers' assessment preferences for EFL performance do not differ based on their in-service training background. However, both the teachers with and those without in-service assessment training scored higher in assessment as learning as in the Table 4.

Interestingly, the results presented in Table 4 and Table 5 indicate that the teachers do not change their assessment preferences significantly regardless of whether they receive assessment training during or before service and that they frequently rely upon their personal assessment preferences.

Table 6. Comparison of teachers' assessment preferences by the number of courses taught in a week

\begin{tabular}{|c|c|c|c|c|c|c|c|c|c|}
\hline \multirow[t]{2}{*}{$\begin{array}{l}\text { Number of courses taught } \\
\text { in a week }\end{array}$} & \multicolumn{2}{|c|}{$\begin{array}{l}\text { Lower } \\
\text { than } 15 \\
\text { hours }\end{array}$} & \multicolumn{2}{|c|}{$\begin{array}{l}16-20 \\
\text { hours }\end{array}$} & \multicolumn{2}{|c|}{$\begin{array}{l}21-25 \\
\text { hours }\end{array}$} & \multicolumn{2}{|c|}{$\begin{array}{l}\text { More than } \\
25 \text { hours }\end{array}$} & \multirow[t]{2}{*}{$\mathrm{F}$} \\
\hline & $\mathrm{m}$ & $\mathrm{sd}$ & $\mathrm{m}$ & $\mathrm{sd}$ & $\mathrm{m}$ & $\mathrm{sd}$ & $\mathrm{m}$ & $\mathrm{Sd}$ & \\
\hline Assessment as learning & 3.90 & .54 & 3.71 & .88 & 3.69 & .85 & 3.97 & .85 & 2.241 \\
\hline Assessment of learning & 3.80 & .77 & 3.88 & .78 & 3.62 & 1.01 & 4.01 & .88 & 2.651 \\
\hline Assessment for learning & 4.16 & .64 & 4.20 & .69 & 3.83 & 1.02 & 4.23 & .85 & 2.330 \\
\hline Assessment for instruction & 3.77 & .71 & 3.80 & .78 & 3.53 & .92 & 3.91 & .79 & 2.180 \\
\hline Assessment to inform & 3.55 & .74 & 3.81 & .84 & 3.41 & 1.01 & 3.91 & .85 & $4.197 *$ \\
\hline
\end{tabular}

An ANOVA analysis was conducted to examine whether teachers' assessment preferences of EFL performance differ based on the number of teaching hours in a week. The results presented in Table 6 show that teachers who teach more than 25 hours weekly scored significantly higher than those who teach less for all factors. However, only one significant difference for the assessing to inform factor was obtained, indicating that the teachers prefer 
assessment to inform to the others when they teach for more than 25 hours in a week.

Table 7. Comparison of the teachers' assessment preferences by the frequency of quizzes given weekly and monthly

\begin{tabular}{|c|c|c|c|c|c|c|c|c|c|c|c|}
\hline \multirow[t]{2}{*}{ Frequency of Quizzes } & \multicolumn{2}{|c|}{ Monthly } & \multicolumn{2}{|c|}{ Twice a month } & \multicolumn{2}{|c|}{$\begin{array}{c}\text { Three } \\
\text { times } \\
\text { in a week }\end{array}$} & \multicolumn{2}{|c|}{ Weekly } & \multicolumn{2}{|c|}{ Never } & \multirow[t]{2}{*}{$\mathrm{F}$} \\
\hline & $\mathrm{m}$ & $\mathrm{sd}$ & $\mathrm{m}$ & $\mathrm{sd}$ & $\mathrm{m}$ & $\mathrm{sd}$ & $\mathrm{m}$ & $\mathrm{sd}$ & $\mathrm{m}$ & sd & \\
\hline Assessment as learning & 3.84 & .85 & 3.78 & .92 & 3.90 & .65 & 4.11 & .83 & 3.42 & .83 & 1.205 \\
\hline Assessment of learning & 3.89 & .84 & 3.80 & .95 & 3.82 & .79 & 4.11 & .79 & 3.60 & 1.16 & .603 \\
\hline Assessment for learning & 4.22 & .78 & 3.95 & 1.02 & 4.20 & .79 & 4.30 & .72 & 3.58 & .70 & 1.591 \\
\hline Assessment for instruction & 3.87 & .77 & 3.73 & .89 & 3.70 & .87 & 3.75 & .77 & 3.04 & .99 & 1.766 \\
\hline Assessment to inform & 3.76 & .88 & 3.65 & .95 & 4.08 & .89 & 3.80 & .70 & 3.50 & 1.12 & .626 \\
\hline
\end{tabular}

Table 7 indicates that there was no significant difference among teachers' assessment preferences of EFL performance as a function of the frequency with which they give quizzes to students. In other words, the teachers' assessment preferences do not change significantly based on the number of quizzes. Further, it was revealed that teachers who give quizzes weekly scored higher than those who give quizzes twice a month, three times in a week and monthly, except for the assessment for instruction and assessing to inform factors. Yet, teachers who give quizzes monthly scored higher on the assessment for instruction factor and teachers who give quizzes three times in a week scored higher on the assessment to inform factor than others.

\section{Discussion and Conclusion}

The descriptive results indicate that the teachers give less importance to listening and writing skills than to reading and speaking skills, and that nearly half of the teachers give equal importance to the four basic foreign language skills in their teaching. EFL reading is mostly perceived to be a skill that teachers may expect learners to acquire (Brown, 2004, p.185). The common ideas about reading skills at K-12 level are that it is "the backbone of most overall assessments, including statewide assessments, that all K-12 students must take. Teachers need to consider how certain question types may negatively impact ELLs scores regardless of their language proficiency" (Coombe, Folse, \&Hubley, 2007, p.43). Zen (2005) describes how, as a relatively new venture, writing has always received less attention in foreign language education history. For a long time, the emphasis in a foreign language class lay predominantly on developing linguistic skills such as the lexicon and grammar. This was because the goal of language learning at that time, when communication by students in the target language in the oral or written form was not important, was "to learn a language in order to read its literature or in order to benefit from the mental discipline and intellectual development" (Richards and Rodgers, 2001, p. 5 quoted in Zen, 2005, p.4). This situation may indicate the unsuccessful adaptation of EFL teachers to new and sophisticated ideas in language teaching such as the constructivist approach.

On the one hand, listening can be counted the most difficult skill, as learners feel that 
understanding every word is essential under superfluous stress and, in this respect teachers' roles have paramount importance in preparing them for the task, encouraging pupils to anticipate the listening task, and helping them to concentrate on the message of the task (Cabrera \& Bazo, 2002). On the other hand, teaching writing is frequently neglected in EFL writing educational processes before higher education and therefore students experience difficulties in communicating through writing. Nonetheless, teaching writing both improves students' writing competence and fosters their language acquisition, cognitive development and learning in general (Zen, 2005). Interestingly, while EFL students at Turkish universities may score highly in foreign language proficiency tests in university entrance exams, they may experience some level of difficulty in writing. As Zen (2005) maintained, this situation is rather usual with foreign language learners and the reason is that students have received inadequate and inappropriate training. Next, the teachers most frequently assess reading skills. Teachers mostly align their teaching with assessment. Reading skills maybe counted as the most fundamental skill for achievement in all educational contexts, and this skill is also of the utmost significance in terms of assessing general language ability (Brown, 2004, p.185).

The teachers reported that speaking is the most challenging skill to assess, while reading is the least challenging skill. Further, the teachers most frequently assess speaking skills through role-plays rather than picture description, problem-solving tasks (e.g. pair-work or group work) or interviews, while most of the teachers assess reading comprehension through true/false and multiple-choice questions, using the ordering ideas task strategy less frequently. Assessing productive skills (e.g. speaking and writing) directly can be more complex and challenging than indirect assessment through multiple-choice (e.g. Barkaoui, 2008, Hamp-Lyons, 1991, 1995, Huang, 2007). As a productive skill, speaking can be assessed directly, although the test-taker's listening skill and elicitation techniques can impact the reliability and validity of assessment (Brown, 2004, p.141).

Male and female teachers have similar assessment preferences in their teaching process. Yet, they mostly prefer assessment practices that focus on assessment as learning, rather than assessment to inform. This result suggests that the teachers mostly assess their students to develop and support their metacognition (Manitoba Education, 2006), rather than to focus on the communicative function of assessment (Gonzales \&Aliponga 2012). This result is complementary to the previous research (Gonzales, 1999; Gonzales \&Aliponga, 2012).

This study also examined whether teachers' assessment preferences of EFL performance differ based on the number of students. Two significant differences for the factors of assessment for instruction and assessment to inform were obtained, indicating that class size impacts upon the teachers' assessment preferences. This result is supported by previous research (Gonzales, 1999; Gonzales \&Aliponga, 2012). In more crowded classes, the teachers tend to attend more to the communicative function of assessment in terms of "reporting and utilizing results for various stakeholders" (Jones \& Tanner, 2008 cited in Gonzales \& Aliponga, 2012, p.5) and providing each student with feedback to enhance their learning (Earl \& Katz, 2006).

Next, pre-service assessment training did not impact upon the teachers' assessment 
preferences, indicating that their assessment preferences for EFL performance do not differ based on their pre-service training background. This result is not supported by earlier research (Gonazales \&Aliponga, 2012). Similarly, the teachers' assessment preferences for EFL performance do not differ based on their in-service training background. Interestingly, the teachers do not change their assessment preferences regardless of whether they receive assessment training during or before service and they frequently rely upon the use of their personal assessment preferences.

Further, the results suggested that the teachers prefer assessment to inform to the others when they teach more than 25 hours in a week. Finally, this study established that the teachers' assessment preferences do not change significantly based on the number of quizzes given weekly or monthly. In the light of this, these teachers may not follow a constructivism based approach in the language teaching process.

Overall, the teachers attended more to assessment as learning irrespective of their gender or of receiving pre-service or in-service assessment training. This suggests that the teachers take the students' role into consideration in their teaching. In other words, the students are perceived as "a critical connector" (Manitoba Education, 2006, p.13) between the assessment and learning process as they actively contribute to the assessment through utilizing information and relating it to their existing knowledge. By doing this, the teachers support student metacognition (Earl, 2003). On the other hand, in this study, the teachers attended more to assessment for instruction, to inform and for learning when the teaching process became more complex and burdensome because of crowded classrooms, an increased number of quizzes given and of teaching hours. In such circumstances, the teachers assess students to provide feedback in order to improve their learning process, to enhance the quality of classroom instruction and to provide information to parents and the school administration about the students' performance in school (Earl, 2003, Gonzales \&Aliponga, 2012).

Briefly, receiving pre-service and in-service training in the assessment of students' performance and in how to support their metacognition was found to be ineffective. Teachers should receive detailed constructivism-based training in higher education and after appointment. Teaching hours, crowded classrooms, low quality and insufficient classroom facilities and materials, textbooks, and teacher competencies are other issues which need to be focused on to enhance constructivist foreign language teaching. Further qualitative research is needed to examine this catastrophe and the discrepancy between the intended constructivism-based approach to language education and the present application of foreign language instruction in Turkey.

In conclusion, this study discussed two facets of EFL performance assessment in Turkey, and it raised important issues for constructivism-based instruction in Turkey, which can be summarized in the following three questions:

1) How should classroom-based EFL performance assessment be performed? 
2) How should Turkish EFL teachers be trained to assess EFL performance in constructivism-based instruction contexts?

3) How should class size, assessment frequency, teaching loads and teachers' assessment practices be aligned with the intended constructivist approach?

\section{References}

Akar, H. (2003). Impact of Constructivist Learning Process on Preservice Teacher Education Students' Performance, Retention, and Attitudes. (Unpublished PhD Thesis). Middle East Technical University, Turkey.

Arslan, A. (2009). Yapılandırmacı Öğrenme Yaklaşımı ve Türkçe Öğretimi. Atatürk Üniversitesi Sosyal Bilimler Enstitüsü Dergisi, 13 (1), 143-154.

Arslani M. (2007). Constructivist Approaches in Education. Ankara University Journal of Faculty of Educational Sciences, 40(1), 41-61.

Bachman, L., \& Palmer, A. (2010). Language assessment practice. Oxford: Oxford University Press.

Barkaoui, K. (2008). Effects of Scoring Method and Rater Experience on ESL Essay Rating Processes and Outcomes. (Unpublished Doctoral Dissertation). Canada: University of Toronto.

Brown, H. Douglas (2004). Language assessment: Principles and classroom practices. White Plains, NY: Pearson Education

Cabrera, M.P., \& Bazo, P. (2002). Teaching the four skills in the primary EFL classroom. The Internet TESL Journal, [Online] Available: http://iteslj.org/Techniques/Bazo-FourSkills.html (December 18, 2013)

Christie, A. (2005). Constructivism and its implications for educators. [Online] Available: http://alicechristie.com/edtech/learning/constructivism/index.htm (December 23, 2013).

Coombe, C., Folse, K., \& Hubley, N. (2007). A practical guide to assessing English language learners. USA: The University of Michigan Press.

Earl, L. (2003). Assessment as learning: Using classroom assessment to maximize student learning. Experts in Assessment Series. California: Corwin Press, inc.

Earl, L., \& Katz, S. (2006). Rethinking Classroom Assessment With Purpose in Mind. Western and Northern Canadian Protocol for Collaboration in Education. [Online] Available: http://www.wncp.ca/english/subjectarea/classassessment.aspx (February 9, 2012).

Gonzales, R. DLC. (1999). Assessing thinking Skills in the Classroom: Types, Techniques And Taxonomy of Measures of Thinking Skills in Higher Education. Philippines Journal of Educational Measurement, 9(1), 17-26.

Gonzales, R., \& Aliponga, J. (2012). Classroom Assessment Preferences of Japanese Language Teachers in the Philippines and English Language Teachers in Japan. MEXTESOL 
Journal, 36 (1), 1-19.

Hamp-Lyons, L. (1991). Scoring Procedures for ESL contexts. In L. Hamp-Lyons (Ed.), Assessing Second Language Writing in Academic Contexts (pp. 241-277). Norwood, NJ: Ablex.

Harris, M., \& McCann, P. (1994) Assessment. Oxford: Heinemann.

Heaton, J. B. (1975). Writing English language tests. London: Longman Group Ltd.

Huang, J. (2007). Examining the Fairness of Rating ESL Students' Writing on Large-Scale Assessments. (Unpublished Doctoral Dissertation). Canada: Queen's University.

Kaufman, D. (2004). 14. Constructivist issues in language learning and teaching. Annual Review of Applied Linguistics, 24, 303-319. http://dx.doi.org/10.1017/S0267190504000121.

Manitoba Education, Citizenship, and Youth. (2006). Rethinking Assessment with Purpose in Mind: assessment for learning, assessment as learning, assessment of learning. Winnipeg, Manitoba, Canada: MECY. [Online] Available: http://www.edu.gov.mb.ca/k12/assess/wncp/rethinking_assess_mb.pdf (December 2, 2013).

McNamara, T. (2000). Language Testing. Oxford: Oxford University Press.

Office of Learning and Teaching, DE \& T. (2005) Current Perspectives on Assessment. [Online]

Available: http://www.eduweb.vic.gov.au/edulibrary/public/teachlearn/student/assessment_current_per.p df (20 November, 2013).

Rueda, R., \& Garcia, E. (1996). Teachers' Perspectives on Literacy Assessment and Instruction With Language-Minority Students: A Comparative Study. The Elementary School Journal, 96(3), 311-332. http://dx.doi.org/10.1086/461830

Rust, C., O'Donovan, B., \& Price, M. (2005). A Social Constructivist Assessment Process Model: How the Research Literature Shows Us This Could Be Best Practice. Assessment \& Evaluation in Higher Education, 30(3), 231-240. http://dx.doi.org/10.1080/02602930500063819

Zen, D. (2005). Teaching ESL/EFL Writing beyond Language Skills. Paper presented at the 3rd International Annual LATEFL China Conference, Tonghua, China. [Online] Available: http://files.eric.ed.gov/fulltext/ED502622.pdf (December 18, 2013).

\section{Copyright Disclaimer}

Copyright reserved by the author(s).

This article is an open-access article distributed under the terms and conditions of the Creative Commons Attribution license (http://creativecommons.org/licenses/by/3.0/). 